\author{
Наталія Салига, \\ кандидат педагогічних наук, \\ доцент кафедри педагогіки та освітнього \\ менеджменту імені Богдана Ступарика \\ ДВНЗ «Прикарпатський національний \\ університет імені Василя Стефаника» \\ (м. Івано-Франківськ, Україна) \\ Nataliia Salyha, \\ Candidate of Pedagogical Scienses, Assosiate Proffesor, \\ Vasyl Stefanyc Precarpathian National University \\ (Ivano-Frankivsk, Ukraine) \\ natalii58@ukr.net
}

УдК 371.15+377.112.4+371.13+378.22.

\title{
ФОРМУВАННЯ МЕТОДИЧНОЇ КУЛЬТУРИ МАЙБУТНІХ ВИКЛАДАЧІВ ЗАКЛАДІВ ВИЩОЇ ОСВІТИ НА ЕТАПІ ПРОФЕСІЙНОЇ ПІДГОТОВКИ
}

\begin{abstract}
Анотація. Стаття присвячена проблемі формування методичної культури майбутніх викладачів закладів вищої освіти на етапі професійної підготовки. Особлива увага приділена необхідності підготовки майбутніх викладачів до роботи зі студентською молоддю. У статті представлено характеристики методичної культури викладача закладу вищої освіти, обґрунтовано необхідність її формування для успішної професійної діяльності в умовах оновлення вищої школи, проаналізовано особливості та функціональні можливості педагогічного середовища, його роль у системі професійної підготовки майбутніх викладачів. Проаналізовано наукові підходи щодо визначення поняття «методична культура», уточнено сутність феномена «методична культура майбутнього викладача ЗВО». Запропоновано шляхи формування методичної культури майбутнього викладача на етапі магістерської підготовки. Дотримання педагогічних умов (наповнення змісту навчальних дисциплін знаннями про методичну культуру викладача ЗВО; використання інтерактивних технологій з метою підвищення мотивації до формування власної методичної культури; врахування вікових особливостей студентської молоді тощо) забезпечує постійний цілеспрямований вплив на формування досліджуваної нами якості.

Автор доводить актуальність формування методичної культури викладача як однієї 3 важливих особистіснопрофесійних якостей та зазначає, що це складне, багаторівневе і системне утворення. У статті підкреслено, що зміст предметів психолого-педагогічного циклу, які викладаються студентам спеціальності «Освітні, педагогічні науки», сприяє зростанню професіоналізму, збагаченню знань, забезпечує розвиток цілісної творчої особистості та формує методичну культуру майбутніх викладачів ЗВО на етапі професійної підготовки. Методи дослідження спрямовувалися на опис сутності змісту статті, цілісного уявлення про проблему, зазначену у темі. Результати наукової розвідки засвідчили, що нагальною сьогодні $є$ потреба удосконалити наукові уявлення про суть та структуру поняття «методична культура майбутнього викладача ЗВО", виявити її структурні компоненти, принципи та фактори формування. Подальшої уваги заслуговує розгляд питання методичної культури майбутнього викладача, яка спрямована на підвищення ефективності його майбутньої діяльності та розвиток професійно-особистісних якостей.
\end{abstract}

Ключові слова: заклад вищої освіти, професійна діяльність, майбутній викладач, методична культура.

\section{DEVELOPMENT OF METHODOLOGICAL CULTURE OF FUTURE LECTURERS OF HIGHER EDUCATION INSTITUTIONS AT THE STAGE OF PROFESSIONAL TRAINING}

Abstract. The article deals with the problem of developing the methodological culture of future lecturers of higher education institutions ( $\mathrm{HEI})$ at the stage of professional training. It is focused on the need to prepare future lecturers to working with student youth.

The article presents the characteristics of the methodological culture of a lecturer of higher education institution, substantiates the necessity of its development for successful professional activity in conditions of reforms in higher education, analyzes the features and functionality of the pedagogical environment, its role in the system of professional training of future lecturers. It analyzes scientific approaches to the definition of the concept of «methodological culture» and specifies the nature of the phenomenon called «methodological culture of the future HEI lecturer». It offers the ways to develop the methodological culture of the future lecturer at the stage of obtaining the master's degree as well.

The relevance of the article is evident in the substantiation of the content and components of the methodological culture of the future HEl lecturer; in the training of a lecturer who has mastered new technologies, methods, forms, means of teaching and educating student youth; in identifying potential opportunities within the educational space of an higher education institution.

Abiding by pedagogical conditions (filling the content of disciplines with knowledge about methodological culture of the HEl lecturer; use of interactive technologies in order to increase the motivation of students to develop their own 
methodological culture; taking into account age-related peculiarities of student youth) provides constant purposeful influence on development of the researched quality.

The author proves the importance of developing the methodological culture of the lecturer as one of the important personal and professional qualities and notes that this is a complex, multilevel and systematic formation. The article emphasizes that the content of the subjects of the psychological and pedagogical cycle taught in the specialty «Educational, Pedagogical Sciences» promotes the growth of professionalism, enrichment of knowledge as well as ensures the development of a holistic creative personality and forms the methodological culture of future lecturers.

Despite the large number of scientific papers dealing with the study of various aspects of the methodological culture of the future lecturers of higher education institution, it should be noted that there is no well-established definition of this concept in the psychological and pedagogical literature yet.

Research methods were aimed at describing the essence of the article content, a presenting the holistic view of the problem mentioned in the title.

The results of scientific research showed that there is an urgent need to improve scientific idea about the essence and structure of the concept of «methodological culture of the future HEl lecturer», to identify its structural components, principles and factors of its formation. Research of the methodological culture of the future lecturers with an aim to improve the efficiency of further professional activity and development of their professional and personal qualities deserves further consideration.

Keywords: higher education institution, professional activity, future lecturer, methodological culture.

\section{ВСТУП}

Постановка проблеми. В умовах реформаційних процесів, які відбуваються у сучасному суспільстві, спостерігається підвищення інтересу вчених до аналізу проблем професійної підготовки викладача закладу вищої освіти (ЗВО). Адже саме йому належить здійснювати практичну реалізацію розпочатих реформ. Для цього викладач ЗВО має глибоко усвідомлювати місце та роль освітніх процесів у світовому культурному просторі, поєднувати глибокі фундаментальні теоретичні знання, бути готовим до здійснення ефективної професійної діяльності.

Необхідною складовою не тільки професійної майстерності педагога, але й освітнього процесу в цілому є методична культура. Зростання значущості методичної діяльності в роботі викладача ЗВО підвищує вимоги саме до його методичної культури, вимагає нового осмислення її суті. Тобто завданням сучасного закладу вищої освіти $€$ не тільки давати теоретичні знання майбутнім педагогам, але й формувати креативного викладача. При цьому у процесі його підготовки повинні бути реалізовані два важливих аспекти - професійний та культурний. Це зумовлює важливість методичної підготовки майбутніх викладачів ЗВО, адже сьогодні немає жодного сумніву, що неналежна увага до цієї проблеми призведе до падіння якості професійної діяльності, зниження її ефективності.

Аналіз наукових досліджень і публікацій. Аналіз сучасних наукових публікацій уможливлює висновок, що увага більшості провідних учених в основному зосереджена на дослідженнях проблеми методичної підготовки вчителів закладів початкової та середньої освіти. Не так багато за останні десятиріччя публікацій, присвячених дослідженню проблеми методичної культури майбутнього викладача ЗВО.

Вчені, які спеціально займаються питаннями вдосконалення змісту професійної освіти (Дубасенюк О., Гриньова Т., Зязюн І., Кремень В. та ін.) зазначають, що, на жаль, підготовка майбутнього викладача у закладах вищої освіти не забезпечує його конкурентоспроможності та високого рівня професіоналізму. Проблемі методичної культури педагога присвятили свої наукові напрацювання Ковтун Г., Лаврентьєва О., Мартиненко О., Нікула Н., Симоненко Л. та ін.

Вчені Зубков О., Княжева І., Мартиненко Г., Нікуліна Н. відзначають, що методична культура викладача ЗВО $€$ стрижнем його професійно-педагогічної культури, яка допомагає вийти на якісно новий загальнонауковий, дослідницький рівень, робить його основні функції в освітньому процесі ефективними та дієвими.

Дослідники Таможня О., Павленко О., Федірчик Т. визначають стратегії розвитку методичної культури майбутнього викладача ЗВО на етапі магістерської підготовки.

Незважаючи на значну кількість досліджень, проблема методичної культури майбутнього викладача ЗВО поки що представлена фрагментарно, оскільки розкриває тільки загальні аспекти і потребує теоретичного дослідження та практичного розв'язання. Малодослідженими залишаються проблеми функцій, визначення сутності методичної культури як цілісного утворення, характерних особливостей формування та ін. Ця проблема потребує подальшого дослідження.

\section{МЕТА І ЗАВДАННЯ ДОСЛІДЖЕННЯ}

Усунення суперечності між необхідністю перетворення методичного досвіду в надбання майбутнього викладача 3ВО, формування його наукового світогляду та недостатньою мотивацією до підвищення рівня власної методичної культури в умовах сьогодення вплинули на обрання мети дослідження - здійснити аналіз теоретичних аспектів особливостей формування методичної культури майбутніх викладачів ЗВО, схарактеризувати її складові, окреслити шляхи оптимізації на етапі професійної підготовки.

\section{МЕТОДИ ДОСЛІДЖЕННЯ}

Для досягнення окресленої мети використовувалися методи дослідження: аналіз науково-педагогічної літератури, синтез, узагальнення, систематизація, що дозволило виявити особливості процесу формування методичної культури майбутніх викладачів ЗВО. 


\section{РЕЗУЛЬТАТИ ДОСЛІДЖЕННЯ}

Наукові проблеми, що пов'язані з формуванням у майбутніх викладачів ЗВО методичної культури, залишаються у полі зору сучасних науковців. Сьогодні у науковому обігу з'явився новий феномен - методична культура викладача, який $є$ правомірною та нагальною потребою часу. I хоча на сьогоднішній день існує значна кількість наукових напрацювань у цьому напрямку, однак поняття «методична культура викладача ЗВО» ще остаточно не прийнято в науковій літературі та знаходиться тільки на етапі свого становлення.

Упродовж тривалого періоду досліджуваний нами феномен висвітлювався тільки в контексті професійнопедагогічної культури педагога, «який впливає на успішність виконання провідної діяльності - конструювання нового знання і обґрунтування доцільного для цього інструментарію» (Лаврентева О., 2015).

Тільки наприкінці XX ст. досліджувана нами проблема стала активніше вивчатись науковцями. Так, Барабанщиков А., Бондаревська $Є$. ., Гриньова В. та ін. присвятили свої дослідження умовам, принципам та методам формування професійно-педагогічної культури педагога.

Фіцула М. небезпідставно вважає, що професійна діяльність викладача закладу вищої освіти «спрямована на навчання, виховання й розвиток студентів, формування у них професійних умінь та навичок, виховання активної життєвої позиції. Педагог сучасного ВНЗ у своїй професійній діяльності поєднує функції викладача, науковця, менеджера, які реалізуються в таких видах діяльності: методична (підвищення якості навчально-виховного процесу, забезпечення його відповідними засобами і матеріалами, при цьому методична культура викладача - це показник його високої творчої активності та вагомий чинник удосконалення процесу освіти)» (Фіцула М., 2006).

3 цього приводу слушно зауважує Кремень В.: «Ключовою фігурою в освітньому процесі $€$ саме педагог, який повинен мати найвищий рівень особистісно-орієнтованої педагогічної та науково-педагогічної культури, яка розкривається через гуманістичну позицію; психолого-педагогічну компетентність та мислення; освіченість, уміння працювати зі змістом і технологіями навчання; здатність до творчості; культури професійної поведінки; уміння саморегуляції власної діяльності» (Кремень В., 2009).

Сушенцева Л. справедливо наголошує, що в умовах сучасних реалій вимоги до викладача зовсім інші, ніж кілька десятків років тому: «Змінилися зміст, методи, форми, засобів навчання й виховання та переосмисленні ролі особистості педагога професійного навчання, вимог до рівня його загального та професійного розвитку, фахової майстерності тощо» (Сушенцева Л., 2013).

Сучасні вчені (Лаврентьєва О., Мартиненко О., Ковтун Г. та ін.) справедливо вважають, що методична культура педагога допомагає перетворити методичний досвід у надбання майбутнього фахівця, фактор розвитку його особистості, творчого мислення, формування наукового світогляду й ціннісної позиції.

Серед головних якостей викладача ЗВО Федірчик І. виділяє «систематичне і планомірне підвищення своєї професійної компетентності; готовність до творчої професійної діяльності; уміння адекватно оцінювати свій рівень професійної компетентності» (Федірчик Т., 2013).

Ми погоджуємося із Княжевою І., яка виокремлює культурологічну та педагогічну складові методичної культури майбутніх викладачів 3ВО, відзначаючи, що кожна з них виконує певні функції, а саме: «регулятивну (управління процесом формування певного набору професійно-особистісних якостей); креативну (вміння знайти правильне вирішення будь-якої педагогічної ситуації); інформаційну (відбір інформації, інтеграція навчального та наукового матеріалу, використання інформаційно-комунікативних технологій); комунікативну (взаємодія магістрів між собою та з викладачем); когнітивну для (зростання та професіоналізація, гуманізація освітнього процесу), прогностичну (визначення перспектив подальшого розвитку освіти)» (Княжева І., 2013).

Ми розділяємо точку зору вченої, яка характеризує сутнісні ознаки феномена «методична культура майбутнього викладача ЗВО», під яким вона розуміє «системне динамічне особистісне утворення, що включає себе ряд компонентів, має власну структуру, вибірково взаємодіє із зовнішнім середовищем і володіє інтегративною властивістю цілого, що не зводиться до властивостей окремих частин. Виокремлення феномену методичної культури педагога як інтегративної характеристики його загальної і професійно-педагогічної культури, зумовлене специфікою педагогічної діяльності, процесом досягнення внутрішньої взаємовідповідності компонентів змісту педагогічної культури» (Княжева І., 2011).

Низка вчених (Зязюн І., Кремень В., Павленко О., Федірчик Т. та ін.) вказують на недостатній рівень професійної підготовки майбутнього педагога у закладах вищої освіти. 3 метою її покращення Зязюн І. пропонує забезпечити реальну підготовку, а саме: «педагога-дослідника, який володіє методами наукового пізнання й інтерпретації даних, здатного до метапредметного осмислення навчального матеріалу; педагога, який вільно володіє іноземною мовою й комп'ютерними технологіями; педагога-психолога, здатного бачити в дитині передусім людину з усіма їі особливостями, бажаннями й проблемами і лише потім - учня, суб'єкта навчання й виховання; педагога, спроможного по-новому організувати навчальний процес, підготувати в достатньому обсязі не лише творців інтелектуальних ресурсів, особливо наукових знань, але й інноваційних особистостей» (Зязюн І., 2004).

Аналіз наукової літератури засвідчує, що для феномена «методична культура майбутнього викладача ЗВо» характерна термінологічна альтернативність, так як його суть по різному трактується дослідниками. Найбільш поширеними в науковій літературі є наступні визначення методичної культури майбутнього викладача ЗВО.

у зв'язку із вищевикладеним, привертає увагу дослідницька позиція Комкової Є. «Методична культура, зазначає вчена, - є багатофункціональним та складним явищем, що шляхом складних взаємозв'язків поєднує в собі, з одного боку, елементи професійно-педагогічної культури, професійної компетентності, а з іншого, - методологічні знання, уміння, здібності, ціннісні детермінанти пізнавальної діяльності та певні індивідуально-гностичні особливості. 
Ї̈̈ структура, ймовірно, за аналогією із загальною культурою повинна включати ядро чи кілька таких концентрів із тих рис особистості вчителя, які вможливлюють духовно-практичне освоєння ним на логічній основі педагогічної діяльності в розмаїтті її проявів» (Комкова Є., 2012).

Нам імпонує точка зору Гершунського Б., який досліджував етапи формування методичної культури, своєрідні ієрархічні «сходинки». «Перша, - вважає дослідник, - це методична грамотність як мінімально необхідний рівень методичних знань, умінь, навичок, творчих, світоглядних і поведінкових якостей особистості, необхідний для здійснення методичної діяльності; основа, стартові можливості для наступного розвитку. Друга сходинка вирізняється кількісними характеристиками своїх складових (об'ємом, широтою і глибиною відповідних знань, умінь, навичок, світоглядних і поведінкових характеристик) - методична освіченість. Третя - методична компетентність, до змісту якої входить володіння різноманітними методами навчання, знання психологічних механізмів засвоєння знань і вмінь у процесі навчання» (Гершунський Б., 1998).

Таможня О. аналізує проблему методичної культури в контексті методичної компетентності та результату професійної підготовки майбутнього педагога, що «виражається в його особистісній і функціональній готовності ефективно виконувати всі види професійної діяльності, що визначаються функціональною структурою методичного мислення. Методична компетентність передбачає здатність викладача до усвідомлення закономірностей своєї професійної діяльності та створення моделі переходу теорії в педагогічну практику. Наступна сходинка методична культура, що передбачає вихід на рівень культури як «вищого прояву людської освіченості і професійної компетентності», на якому може в найповніше виразитися людська індивідуальність. Саме вона дозволяє майбутньому викладачеві не починати свій шлях у професії із «професійної робінзонади», не тільки користуватися колективною мудрістю попередників, бути не лише пасивним її споживачем, а бути генератором, виробником власного досвіду, нових культурних цінностей» (Таможня О., 2010).

У контексті нашої роботи цікавими є матеріали, узагальнені вченим Павленко О., який вважає, що методична культура викладача ЗВО включає: «1) навчально-методичну (діяльність, пов'язану з удосконаленням методів, форм, технологій навчання та методикою викладання конкретної навчальної дисципліни, підготовкою до аудиторних занять, розробкою нормативно-програмного та навчально-методичного забезпечення навчального процесу); 2) науково-методичну (діяльність, спрямовану на вивчення й узагальнення передового досвіду організації навчального процесу у ВНЗ розробку та втілення інноваційних методів і технологій навчання, розробку методів контролю й управління якістю підготовки студентів на всіх етапах навчання, творчу та науково-дослідну роботу викладача для узагальнення й опису результатів своєї науково-дослідної діяльності); 3) організаційно-методичну (діяльність, що потребує від викладача наявності педагогічного досвіду та самоорганізації, розвинутої рефлексії, передбачає участь у роботі вчених і методичних рад ВНЗ, у системі управління ВНЗ (ректор, проректор, декан, завідувач кафедри), у підготовці та проведенні методичних заходів, експертизі забезпечення й методичного супроводу навчального процесу). Після аналізу наукових підходів до вивчення методичної діяльності сформувалось розуміння того, що якість методичної діяльності викладача економіки та її високі результати залежать від сукупності факторів: від рівня розвитку потреб викладача, його мотивації, особистісних якостей і здібностей, від сукупності засобів методичного характеру, що впливають на активність особистості та визначають вибір засобів, прийомів і методів досягнення освітніх цілей. Провадження методичної діяльності неможливе без розвинутої методичної культури викладача економіки. Як видається, у методичній діяльності викладача економіки поступово відбувається перехід знань, умінь, творчих здібностей у внутрішні переконання, що впливає на самосвідомість, саморозвиток викладача економіки» (Павленко О., 2011).

\section{ВИСНОВКИ ТА ПЕРСПЕКТИВИ ПОДАЛЬШИХ ДОСЛІДЖЕНЬ}

Отже, узагальнення напрацювань учених дозволяє нам розуміти під поняттям «методична культура майбутнього викладача ЗВО» один із напрямків його професійної підготовки та обов'язковий компонент професіоналізму. Ґрунтуючись на теоретичному аналізі наукової літератури, можемо дійти висновків, що професійна діяльність майбутнього викладача ЗВО залежить від рівня його методичної культури, яка дозволяє йому стати більш компетентним у питаннях навчання, чітко окреслити його цілі та оптимальні шляхи їх досягнення, відкриває перспективи професійного зростання та вдосконалення майстерності.

Методична культура поєднує навчально-методичну, науково-методичну та організаційно-методичну діяльність і є інтегральною характеристикою особистості майбутнього викладача ЗВО, способом самореалізації у передачі знань, організації процесу навчання, створення умов для повноцінної педагогічної взаємодії. Окрім того, вона містить знання, вміння та навички, практичний досвід у застосуванні методики навчання студентів, готовність розв'язувати різні методичні завдання та здатність до постійного самовдосконалення.

Вважаємо, що у майбутніх викладачів ЗВО не розвинуті достатньою мірою такі навички, як: здатність організувати освітній процес, аудиторну та самостійну роботу, використовувати нові педагогічні та інформаційнокомунікативні технології, конструювати світоглядний зміст лекції, ставити конкретні цілі тощо.

Подальшого вивчення потребує розробка педагогічних умов та етапів формування методичної культури; вивчення стану сформованості методичної культури на етапі магістерської підготовки та під час проходження асистентської практики.

\section{СПИСОК ВИКОРИСТАНИХ ДЖЕРЕЛ}

Гершунский, Б. (1998). Образование в третьем тысячелетии: гармония знания и веры. Педагогика, 2, 49-57.

Гриньова, В. (2001). Формування педагогічної культури майбутнього вчителя (теоретичний та методичний аспекти). Автореф. дис. д-ра. пед. наук. Харківський державний педагогічний університет ім. Г.С. Сковороди, Київ. 
Зубков, О. (2007). Развитие методической компетентности учителей в условиях модернизации общего образования. Автореф. дис. ... канд. пед. наук. Челябинський государственный педагогический университет. Екатеринбург.

Зязюн, І. (2004). Педагогічна майстерність : монографія. Київ: Вища школа.

Княжева, І. (2011). Методична культура педагога як інтегративна характеристика його загальної і професійно-педагогічної культури. Психолого-педагогічні проблеми сільської школи, 39, 44.

Калінська, О. (2016). Сутність та структура педагогічної майстерності викладача вищого навчального закладу. Молодий вчений, 10 (37), 240-244.

Княжева, І. (2013). Методична підготовка майбутніх викладачів педагогічних дисциплін в умовах магістратури. Психолого- педагогічні науки, 1, 177-181.

Козловський, Ю. (2016). Наукова освіта викладача вищого навчального закладу. Сучасні інформаційні технології та інноваційні методики навчання у підготовці фахівців: методологія, теорія, досвід, проблеми, 46, 215-218.

Комкова, Е. (2012). Методология, теория и методы психологических исследований : учебно-методический комплекс. Минск : Из-во миу.

Кремень, В. (2009). Філософія людиноцентризму в стратегіях освітнього простору: монографія. Київ : Педагогічна думка.

Лаврентьєва, О. (2015). Теоретичні і методичні засади розвитку методологічної культури майбутніх учителів природничих дисциплін у процесі професійної підготовки. Автореф. дис. канд. пед. наук. Ін-т пед. освіти і освіти дорослих. Київ.

Мартиненко, О., Ковтун Г. (2016). Формування методичної компетентності вчителя математики та економіки. Педагогічні науки: теорія, історія, інноваційні технології, 3 (57), 398-406.

Нікула, Н. (2016). Критерії та показники сформованості методичної культури майбутніх учителів початкових класів. Актуальні проблеми педагогіки, психології та професійної освіти, 2.

Павленко, О. (2011). Методична діяльність викладача економіки як педагогічна проблема наукові записки. Педагогічні науки, 167. C.35, 33-39.

Симоненко, Л. (2013). Методична компетентність як складник професійної компетентності вчителя української мови. Науковий вісник Донбасу, 2.

Сушенцева, Л. (2013). Мобільність майбутнього педагога професійного навчання. URL: http://lib.iitta.gov.ua/1309/1/stattja_ poland_2013_sushenceva.pdf.

Таможняя, Е. (2010). Система методической подготовки учителя географии в педагогическом вузе в условиях модернизации образования. Автореф дис. док. пед. наук. Московский педагогический государственный университет.

Федірчик, Т. (2013). Професійно значущі якості викладача вищої школи як особистісна складова його педагогічного професіоналізму. Молодь і ринок, 5, 77-82.

Фіцула, М. (2006). Педагогіка вищої школи : навч. посіб. Київ : Академвидав.

\section{REFERENCES}

Gershunskij, B. (1998). Obrazovanie v tret'em tysjacheletii: garmonija znanija i very. Pedagogika, 2, 49-57.

Hrynova, V. (2001). Formuvannia pedahohichnoi kultury maibutnoho vchytelia (teoretychnyi ta metodychnyi aspekty). Avtor. dys. d-ra. ped. nauk. Kharkivskyi derzhavnyi pedahohichnyi universytet im. H.S. Skovorody, Ministerstvo osvity i nauky Ukrainy. Kyiv.

Zubkov, O. (2007). Razvitie metodicheskoj kompetentnosti uchitelej v uslovijah modernizacii obshhego obrazovanija. Avtoref. dis. ... kand. ped. nauk. Cheljabinskij gosudarstvennyj pedagogicheskij universitet. Ekaterinburg.

Ziaziun, I. (2004). Pedahohichna maisternist : monohrafiia. Kyiv: Vyshcha shkola.

Kniazheva, I. (2011). Metodychna kultura pedahoha yak intehratyvna kharakterystyka yoho zahalnoi i profesiino-pedahohichnoi kultury. Psykholohopedahohichni problemy silskoi shkoly, 39, 44-51.

Kalinska, O. (2016). Sutnist ta struktura pedahohichnoi maisternosti vykladacha vyshchoho navchalnoho zakladu. Molodyi vchenyi, 10 (37), $240-244$.

Kniazheva, I. (2013). Metodychna pidhotovka maibutnikh vykladachiv pedahohichnykh dystsyplin v umovakh mahistratury. Psykholoho-pedahohichni nauky, 1, 177-181.

Kozlovskyi, Yu. M. (2016). Naukova osvita vykladacha vyshchoho navchalnoho zakladu. Suchasni informatsiini tekhnolohii ta innovatsiini metodyky navchannia u pidhotovtsi fakhivtsiv: metodolohiia, teoriia, dosvid, problemy 46, 215-218.

Komkova, E. (2012). Metodologija, teorija i metody psihologicheskih issledovanij : uchebno-metodicheskij kompleks. Minsk : Iz-vo MIU.

Kremen, V. (2009). Filosofiia liudynotsentryzmu v stratehiiakh osvitnoho prostoru : monohrafiia. Kyiv : Pedahohichna dumka.

Lavrentieva, O. (2015). Teoretychni i metodychni zasady rozvytku metodolohichnoi kultury maibutnikh uchyteliv pryrodnychykh dystsyplin u protsesi profesiinoi pidhotovky. (Avtoref. dys. kand.ped.nauk). In-t ped. osvity i osvity doroslykh. Kyiv.

Martynenko, O., Kovtun H. (2016). Formuvannia metodychnoi kompetentnosti vchytelia matematyky ta ekonomiky. Pedahohichni nauky: teoriia, istoriia, innovatsiini tekhnolohii, 3 (57), 398-406.

Nikula, N. (2016). Kryterii ta pokaznyky sformovanosti metodychnoi kultury maibutnikh uchyteliv pochatkovykh klasiv. Aktualni problemy pedahohiky, psykholohii ta profesiinoi osvity, 2.

Pavlenko, O. (2011). Metodychna diialnist vykladacha ekonomiky yak pedahohichna problema naukovi zapysky. Pedahohichni nauky, 167, 33-39.

Symonenko, L. (2013). Metodychna kompetentnist yak skladnyk profesiinoi kompetentnosti vchytelia ukrainskoi movy. Naukovyi visnyk Donbasu, 2.

Sushentseva, L. (2013). Mobilnist maibutnoho pedahoha profesiinoho navchannia. Retrieved from http://lib.iitta.gov.ua/1309/1/stattja_poland_2013_ sushenceva.pdf.

Tamozhnjaja, E. (2010). Sistema metodicheskoj podgotovki uchitelja geografii v pedagogicheskom vuze $v$ uslovijah modernizacii obrazovanija. Avtoref dis.dok. ped. nauk. Moskovskij pedagogicheskij gosudarstvennyj universitet.

Fedirchyk, T. (2013). Profesiino znachushchi yakosti vykladacha vyshchoi shkoly yak osobystisna skladova yoho pedahohichnoho profesionalizmu. Molod i rynok, 5, 77-82.

Fitsula, M. (2006). Pedahohika vyshchoi shkoly : navch. posib. Kyiv : Akademvydav. 